Article

\title{
Circular Economy: A Comprehensive Review of Eco-Friendly Wollastonite Applications
}

\author{
Christiano Bruneli Peres ${ }^{1}$, Pedro R. Resende ${ }^{2,3,4, * \mathbb{C}}$, Leonel J. R. Nunes ${ }^{2,5}{ }^{\mathbb{D}}$ and Leandro Cardoso de Morais ${ }^{1}$ \\ 1 Institute of Science and Technology, Sorocaba Campus, São Paulo State University (UNESP) “Júlio de \\ Mesquita Filho", Sorocaba 18087-180, São Paulo, Brazil; christiano.bruneli-peres@unesp.br (C.B.P.); \\ leandro.cardoso@unesp.br (L.C.d.M.) \\ 2 proMetheus, Instituto Politécnico de Viana do Castelo, 4900-347 Viana do Castelo, Portugal; \\ leonelnunes@esa.ipvc.pt \\ 3 Escola Superior de Tecnologia e Gestão, Instituto Politécnico de Viana do Castelo, \\ 4900-348 Viana do Castelo, Portugal \\ 4 CEFT, Faculdade de Engenharia, Universidade do Porto, 4200-465 Porto, Portugal \\ 5 Escola Superior Agrária, Instituto Politécnico de Viana do Castelo, 4990-706 Ponte de Lima, Portugal \\ * Correspondence: pedroresende@estg.ipvc.pt
}

Citation: Peres, C.B.; Resende, P.R.; Nunes, L.J.R.; de Morais, L.C. Circular Economy: A Comprehensive Review of Eco-Friendly Wollastonite Applications. Sustainability 2022, 14, 3070. https://doi.org/10.3390/ su14053070

Academic Editor: Elena Cristina Rada

Received: 5 January 2022

Accepted: 3 March 2022

Published: 6 March 2022

Publisher's Note: MDPI stays neutral with regard to jurisdictional claims in published maps and institutional affiliations.

Copyright: (C) 2022 by the authors. Licensee MDPI, Basel, Switzerland. This article is an open access article distributed under the terms and conditions of the Creative Commons Attribution (CC BY) license (https:// creativecommons.org/licenses/by/ $4.0 /)$.

\begin{abstract}
The growing increase in greenhouse gases, especially carbon dioxide $\left(\mathrm{CO}_{2}\right)$, by anthropogenic activities can be linked to extreme climate events, such as intensive droughts, floods, or hurricanes, and has led to several studies focused on reducing the concentration of this greenhouse gas in the atmosphere. Some technologies, such as carbon capture and storage (CCS), can potentially sequester billions of tons of $\mathrm{CO}_{2}$ per year. One of the promising methods is the use of carbon mineralization as a CCS methodology. For this approach, some minerals can be investigated, such as wollastonite, which can be obtained from agricultural waste recovery. One topic of interest in these studies is agriculture, demonstrating that it can play an important role in climate change mitigation. This work presents a critical review of the studies of rice waste use for potential synthesizing wollastonite as a path for $\mathrm{CO}_{2}$ storage, promoting the circular economy. Several works were analyzed and presented, addressing eco-friendly wollastonite use, such as in the cement industry, and they can contribute to a lower global warming potential. There is a promising way to explore, once there are few studies in the literature about $\mathrm{CO}_{2}$ capture and storage of wollastonite by carbon mineralization.
\end{abstract}

Keywords: circular economy; rice production; wollastonite; carbon capture and storage

\section{Introduction}

Some environmental problems, such as global warming, are directly linked to the increase in the concentration of anthropogenic greenhouse gases, mainly carbon dioxide $\left(\mathrm{CO}_{2}\right)$, corresponding to $68 \%$ of the total emissions [1-3]. In theory, the temperature increase in the lower atmosphere layers is called global warming, which can be enhanced by several human activities, as well as fossil fuel burning, industrial activities, and deforestation, among others. Some sectors stand out in the contribution of the emitted $\mathrm{CO}_{2}$, such as industries that operate with fossil fuels, transportation, cement production, energy, and others [4-8].

In Brazil (2019), the activity with the most $\mathrm{CO}_{2}$ emissions was the land-use change and forests sector ( $\sim 900 \mathrm{Mt}$ of $\left.\mathrm{CO}_{2}\right)$, followed by the energy sector ( $\sim 384 \mathrm{Mt}$ of $\left.\mathrm{CO}_{2}\right)($ Table 1$)$.

According to Friedlingstein et al. [9], the global concentration of $\mathrm{CO}_{2}$ in 2020 was 34.07 $\mathrm{GtCO}_{2}$, and in Brazil, according to SEEG (2019), the total $\mathrm{CO}_{2}$ emission for the year 2019 was $1.38 \mathrm{GtCO}_{2}$. There is a huge global $\mathrm{CO}_{2}$ emission over the years $1750-2020\left(\sim 35 \mathrm{GtCO}_{2}\right)$. Figure 1 provides an overview of the evolution of $\mathrm{CO}_{2}$ emissions in Brazil in the period 1990-2019, and the contribution of the various sectors in terms of greenhouse gas emissions. This shows that the land-use change and forestry sector is highly representative in terms of 
$\mathrm{CO}_{2}$ emissions. In comparative terms, this sector had a $\mathrm{CO}_{2}$ emission in 1990 of $1112 \mathrm{Mt}$ of $\mathrm{CO}_{2}$, reaching a peak of $1976 \mathrm{Mt}$ of $\mathrm{CO}_{2}$ in 2003 and $900 \mathrm{Mt}$ of $\mathrm{CO}_{2}$ in 2019.

Table 1. Brazil's $\mathrm{CO}_{2}$ emissions (\%) by sector (2019) (adapted from http:/ / plataforma.seeg.eco.br/ total_emission, accessed on 16 November 2021).

\begin{tabular}{cc}
\hline Sector & $\mathrm{CO}_{2}$ Emission (\%) \\
\hline Land-use change and forests & 64.90 \\
Energy & 27.68 \\
Industrial processes & 5.60 \\
Agriculture & 1.76 \\
Waste & 0.06 \\
\hline
\end{tabular}

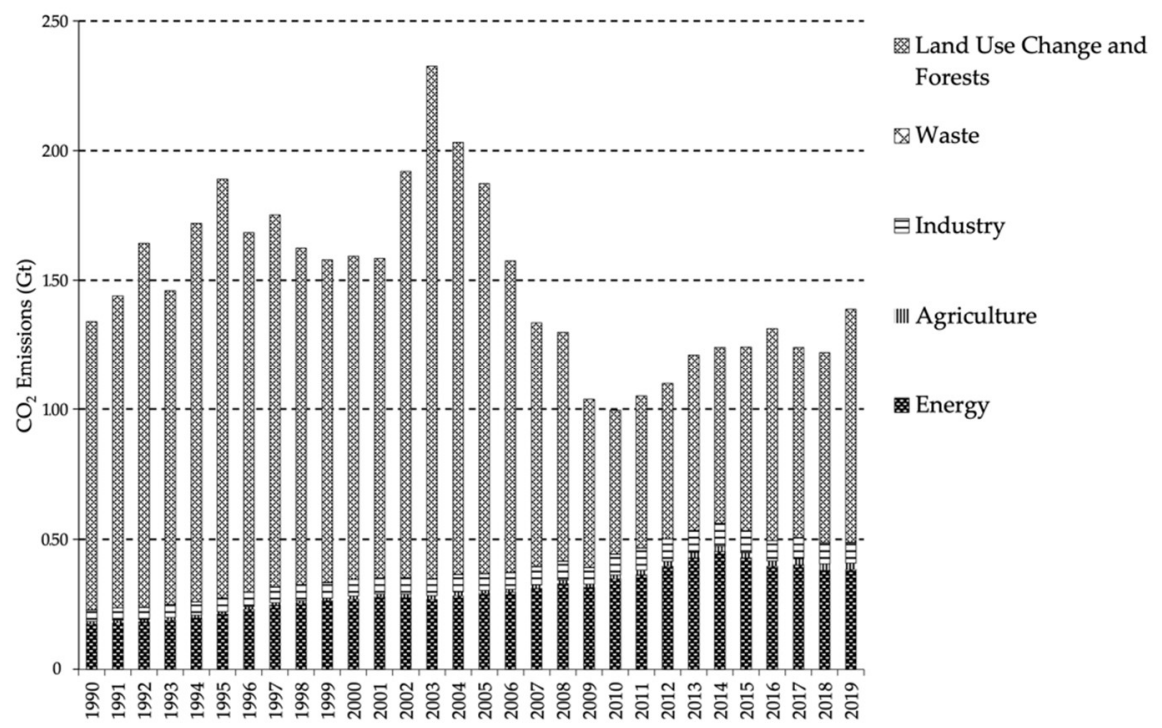

Figure 1. Brazil's $\mathrm{CO}_{2}$ emissions (adapted from http://plataforma.seeg.eco.br/total_emission, accessed on 16 November 2021).

Some extreme weather events such as extreme droughts, rising sea levels, cyclones, hurricanes, negative effects on ecosystems, and reduced biodiversity, among others, are consequences of the high $\mathrm{CO}_{2}$ concentration in the atmosphere, causing huge problems. Reducing this $\mathrm{CO}_{2}$ concentration to curb global warming has been a major challenge [10]. For this, some environmentally friendly solutions have been proposed which involve the circular economy, such as the synthesis of agricultural rice residues for producing a mineral that is very promising in $\mathrm{CO}_{2}$ capture, by the carbon mineralization process. There are few studies in the literature about carbon mineralization of wollastonite and $\mathrm{CO}_{2}$ capture; however, there are several contributions about the synthesis of wollastonite by rice residues [11-13] and carbon mineralization by wollastonite $[8,14-16]$. Thus, a future perspective about using wollastonite for carbon capture and storage is very promising.

This paper aims to bring a review about the potential carbon capture and storage of wollastonite minerals by rice residues for carbon mineralization, promoting a circular economy. First, a short review of the carbon capture and storage technologies is presented. Then, a review of carbon mineralization is used with some chemical reactions, followed by a section about wollastonite as a mineral and rice crop. Finally, a section about the synthesis of wollastonite by a rice residue is proposed, and the impacts of rice cultivation are shown. There are few studies about the $\mathrm{CO}_{2}$ capture and storage of wollastonite synthesized by rice residues, this paper tries to contribute to the state of the art of carbon capture and storage as a methodology to possibly synthesize wollastonite from rice residues. 


\section{Bibliography Review}

\subsection{Carbon Capture and Storage (CCS)}

There are three main mitigation technologies for $\mathrm{CO}_{2}$ : efficient technologies to reduce demand for non-renewable energy; renewable technologies such as solar, wind, and biomass, and carbon capture and storage (CCS) $[8,17-19]$. CCS is one of the key technologies to reduce the rise in global temperature, which is one of the causes of climate change, and for this reason, both the international community and the scientific community have been showing interest in CCS [20]. CCS is an emerging technology to reduce $\mathrm{CO}_{2}$ emissions, and it plays a very important role. One of its great advantages is that it is an emerging low-carbon technology, considered to be the technology of the future, and it is environmentally friendly [21].

Depending on the capture location of the $\mathrm{CO}_{2}, \mathrm{CCS}$ can be divided into:

- Post-combustion capture: Where the $\mathrm{CO}_{2}$ is removed after combustion process;

- Pre-combustion capture: Which involves the separation and storage of $\mathrm{CO}_{2}$ before combustion;

- Oxy-combustion: In which fuel is burned in the presence of oxygen to produce a concentrated current of $\mathrm{CO}_{2}$.

Around the world, there are CCS installations (also called CCUS-carbon capture, storage, and utilization), as can be seen in Table 2 [22]. It is noteworthy that Brazil was also a pioneer in the use of this technology in the Baia de Santos, being responsible for processing natural gas as a source of $\mathrm{CO}_{2}$, capturing about $3 \mathrm{Mt} /$ year of $\mathrm{CO}_{2}$.

Table 2. Main commercial CCUS facilities in operation around the world in 2020 (adapted from [20]).

\begin{tabular}{|c|c|c|c|c|}
\hline Country & Project & In Operation Since & Source of $\mathrm{CO}_{2}$ & $\begin{array}{c}\mathrm{CO}_{2} \text { Capture Capacity } \\
\text { (Mt/Year) }\end{array}$ \\
\hline US & $\begin{array}{l}\text { Shute Creek gas processing } \\
\text { facility }\end{array}$ & 1986 & Natural gas processing & 7.0 \\
\hline US/Canada & $\begin{array}{l}\text { Great Plains Synfuels } \\
\text { (Weyburn/Midale) }\end{array}$ & 2000 & Synthetic natural gas & 3.0 \\
\hline US & Century plant & 2010 & Natural gas processing & 8.4 \\
\hline Brazil & $\begin{array}{l}\text { Petrobras Santos Basin } \\
\text { pre-salt oilfield CCS }\end{array}$ & 2013 & Natural gas processing & 3.0 \\
\hline Canada & Boundary Dam CCS & 2014 & Power generation (coal) & 1.0 \\
\hline Saudi Arabia & $\begin{array}{l}\text { Uthmaniyah } \mathrm{CO}_{2} \text {-EOR } \\
\text { demonstration }\end{array}$ & 2015 & Natural gas processing & 0.8 \\
\hline Canada & Quest & 2015 & Hydrogen production & 1.0 \\
\hline United Arab Emirates & Abu Dhabi CCS & 2016 & $\begin{array}{l}\text { Iron and steel } \\
\text { production }\end{array}$ & 0.8 \\
\hline US & Petra Nova & 2017 & Power generation (coal) & 1.4 \\
\hline US & Illinois Industrial & 2017 & Ethanol production & 1.0 \\
\hline China & Jilin oilfield $\mathrm{CO}_{2}$-EOR & 2018 & Natural gas processing & 0.6 \\
\hline Australia & $\begin{array}{c}\text { Gorgon Carbon Dioxide } \\
\text { Injection }\end{array}$ & 2019 & Natural gas processing & $3.4-4.0$ \\
\hline Canada & $\begin{array}{c}\text { Alberta Carbon Trunk Line } \\
\text { (ACTL) with Agrium } \mathrm{CO}_{2} \\
\text { stream }\end{array}$ & 2020 & Fertilizer production & $0.3-0.6$ \\
\hline Canada & $\begin{array}{l}\text { ACTL with North West } \\
\text { Sturgeon Refinery } \mathrm{CO}_{2} \\
\text { stream }\end{array}$ & 2020 & Hydrogen production & $1.2-1.4$ \\
\hline
\end{tabular}

There are challenges to be faced in developing CCS technologies in several countries, such as in Asia, Latin America, and Africa. One strong cause of this is that in these regions there are no significant sources of carbon funding or expectation of profiting from CCS [2]. In Brazil, the CCS technologies began in the 1990's, especially in the oil industry, with Petrobras. In the Recôncavo Basin/BA (Buracica field), $\mathrm{CO}_{2}$ injection tests started in 1991. 
Other CSS projects in Brazil are Miranga and Porto Batista Carbomethane. The Petrobas Miranga project had three different storage scenarios: oil gas recovery, a depleted gas reservoir, and saline aquifers. The Porto Batista Carbomethane project is responsible for watching over the enhanced coal bed methane production. Nowadays, Brazil is home to one of the largest CCS oil gas recovery projects in the world with the Lula field project in the pre-salt oil [2]. So, a country such as Brazil should invest more resources in CCS technologies, once is a big opportunity to promote $\mathrm{CO}_{2}$ capture and storage. CCS consists of three main processes: $\mathrm{CO}_{2}$ separation of the gaseous flow in question; $\mathrm{CO}_{2}$ transport to the storage location, and sequestration methods of $\mathrm{CO}_{2}$ for gas isolation [23]. For $\mathrm{CO}_{2}$ capture, four main methods are considered: mineral, biological, geological, and ocean sequestration methods, as seen in Figure 2, in addition, the costs of each process are shown [8].

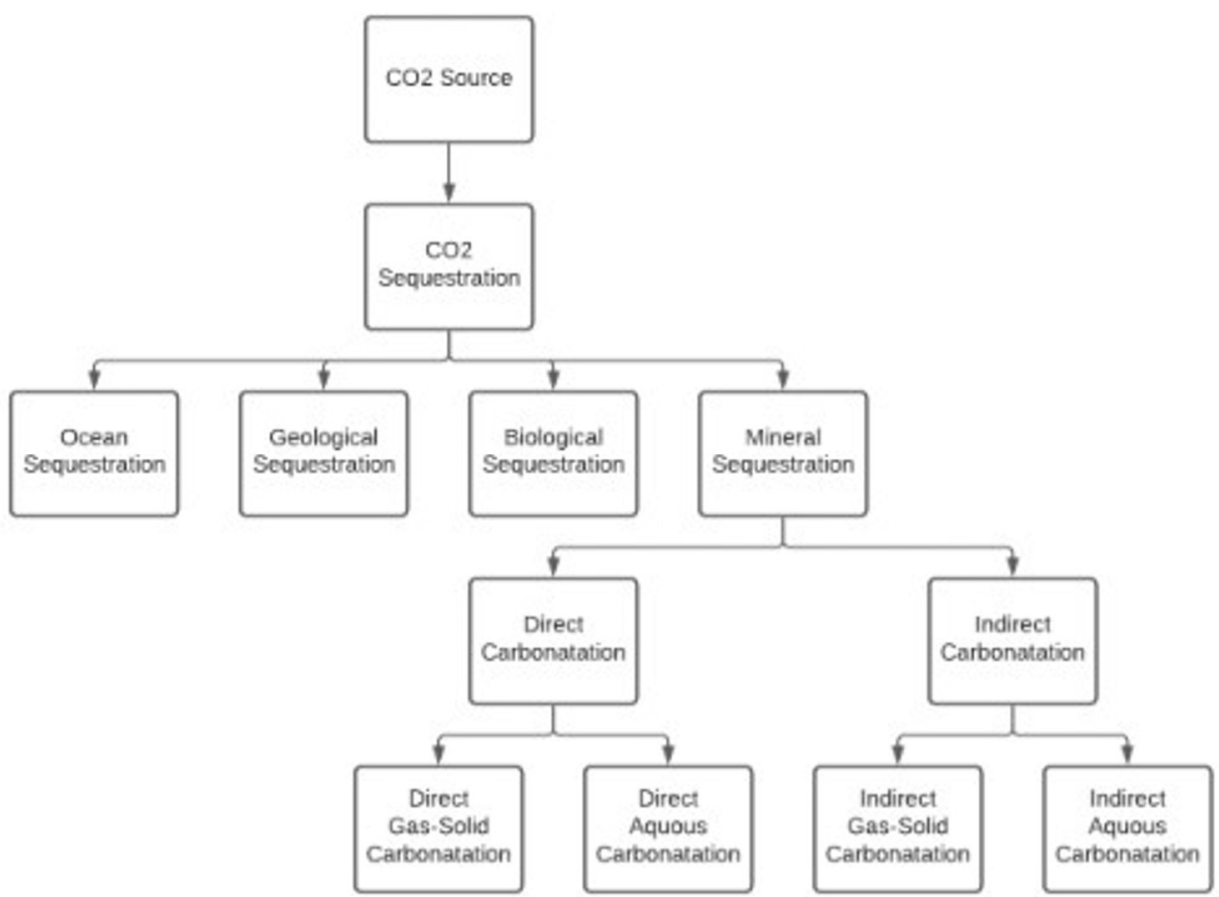

Figure 2. Methods of $\mathrm{CO}_{2}$ sequestration (adapted from [8]).

Table 3 shows the main benefits of each method of $\mathrm{CO}_{2}$ storage and their costs $\left(\mathrm{BRL} /\right.$ ton $\mathrm{CO}_{2}$ ).

Table 3. Storage types of $\mathrm{CO}_{2}$ sequestration and their main benefits and costs (adapted from [8]).

\begin{tabular}{ccc}
\hline Storage Types & Main Benefits & Cost (BRL/ton $\left.\mathbf{C O}_{2}\right)$ \\
\hline Geological & Economical & $0.5-8$ \\
Ocean & Public acceptance & \\
High potential & $6-31$ \\
Biological & Universal availability & Low cost \\
& High potential & $3-10$ \\
Carbon mineralization & Environmentally safe & \\
& Abundance of feedstock & $50-100$ \\
\hline
\end{tabular}

It can be observed that the geological process exhibit lower costs of $\mathrm{CO}_{2}$ storage (BRL 0.5-8/ton $\mathrm{CO}_{2}$ ), on the other hand, carbon mineralization is the higher cost (BRL 50-100/ton $\mathrm{CO}_{2}$ ), this can be explained due to the major cost of carbon mineralization being associated with the energy consumed during the process. Despite the high cost, carbon mineralization is the preferred method of $\mathrm{CO}_{2}$ storage, due to the permanence of 
the $\mathrm{CO}_{2}$ storage [8]. It is known that mineral sequestration (carbon mineralization) has the greatest storage capacity for $\mathrm{CO}_{2}$ and hence its effectiveness is widely studied, as shown in Figure 3. In addition, mineral storage is safer than other methods such as ocean and geological sequestration $[8,14]$.

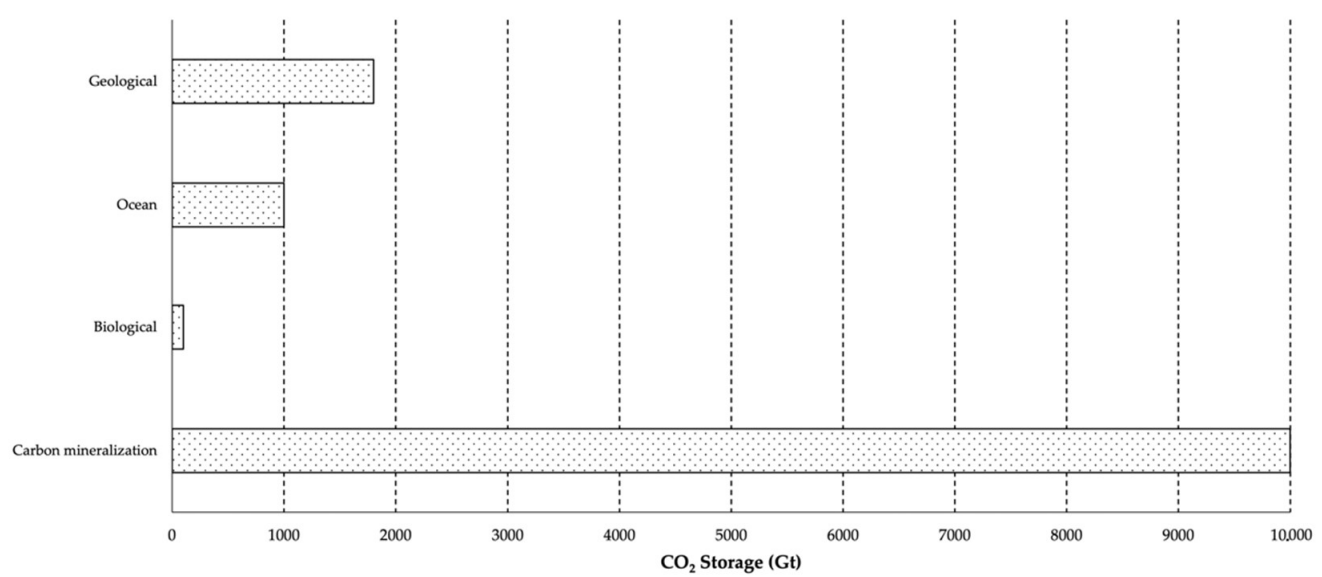

Figure 3. Main $\mathrm{CO}_{2}$ storage methods (adapted from $[8,14]$ ).

For this reason, carbon mineralization emerges as a technology of great interest as a strategy to remove $\mathrm{CO}_{2}$ from the atmosphere. Several minerals can be used for mineral carbonization, such as wollastonite $\left(\mathrm{CaSiO}_{3}\right)$, studied in this work and others, like serpentine and olivine [8]. Wollastonite has a great advantage over other minerals used in carbon mineralization in reactions with silicates (e.g., forsterite $\left(\mathrm{Mg}_{2} \mathrm{SiO}_{4}\right)$, fayalite $\left(\mathrm{Fe}_{2} \mathrm{SiO}_{4}\right)$, and antigorite $\left.\left((\mathrm{Mg}, \mathrm{Fe})_{3} \mathrm{Si}_{2} \mathrm{O}_{5}(\mathrm{OH})_{4}\right)\right)$, wollastonite has faster kinetic reactions [24]. Currently, silicates such as wollastonite are attracting great interest due to their reduced carbon footprint. Wollastonite can also be incorporated into the soil, increasing its fertility $[16,25]$. Wollastonite has been studied by several authors $[16,24,25]$ as a way to capture $\mathrm{CO}_{2}$.

\subsection{Carbon Mineralization}

Carbon mineralization is a non-toxic method used to store $\mathrm{CO}_{2}$ in solid form, the prose process was proposed 30 years ago as a strategy to remove $\mathrm{CO}_{2}$ from the atmosphere [15]. When $\mathrm{CO}_{2}$ dissolved in rainwater reacts with silicates rich in $\mathrm{Ca}$ or $\mathrm{Mg}$ that exist in abundance in nature, mineral carbonation occurs naturally [8]. In the carbon mineralization process, the $\mathrm{CO}_{2}$ reacts with minerals rich in calcium $(\mathrm{Ca})$ and magnesium $(\mathrm{Mg})$ to form stable carbonates such as wollastonite $\left(\mathrm{CaSiO}_{3}\right)$, olivine $\left(\mathrm{Mg}_{2} \mathrm{SiO}_{4}\right)$, calcite $\left(\mathrm{CaCO}_{3}\right)$, magnesite $\left(\mathrm{MgCO}_{3}\right)$, and dolomite $\left(\mathrm{CaMg}\left(\mathrm{CO}_{3}\right)_{2}\right)$ [26]. The best sources of $\mathrm{Mg}$ and $\mathrm{Ca}$ are mafic and ultramafic rocks (basaltic lava), mining tailings, and industrial bioproducts (steel slag and fly ash). In turn, the source of $\mathrm{CO}_{2}$ may vary depending on the context, such as ambient air $\left(\sim 0.04 \% \mathrm{CO}_{2}\right)$ or industrial gas stream $\left(\sim 5-12 \% \mathrm{CO}_{2}\right)$ [15].

Some of the reactions that occurred in the process are shown below:

$$
\begin{gathered}
\text { Wollastonite: } \mathrm{CaSiO}_{3}+\mathrm{CO}_{2} \leftrightarrow \mathrm{CaCO}_{3} \\
\text { Olivine: } \mathrm{MgSiO}_{4}+2 \mathrm{CO}_{2} \leftrightarrow 2 \mathrm{MgCO}_{3} \mathrm{SiO}_{2}
\end{gathered}
$$

The $\mathrm{CO}_{2}$ storage and capture capacity of these materials are 0.62 tons of $\mathrm{CO}_{2}$ per ton of olivine, $\sim 0.4-0.5$ tons of $\mathrm{CO}_{2}$ per tons of wollastonite or industrial waste with a similar composition of wollastonite [26]. In this case, the Ca ion is derived from limestone [26]. For $\mathrm{CO}_{2}$ released during the process, some life cycle assessment (LCA) is required. As wollastonite is the object of study in this work, some chemical reactions that occur during the aqueous carbonization of wollastonite are described in detail below:

$$
\mathrm{CO}_{2(\mathrm{~g})}+\mathrm{H}_{2} \mathrm{O}_{(\mathrm{l})}=\mathrm{H}_{2} \mathrm{CO}_{3(\mathrm{aq})}
$$




$$
\begin{gathered}
\mathrm{H}_{2} \mathrm{CO}_{3(\mathrm{aq})}=\mathrm{H}_{(\mathrm{aq})}{ }^{+}+\mathrm{HCO}_{3(\mathrm{aq})}{ }^{-} \\
\mathrm{HCO}_{3(\mathrm{aq})}=\mathrm{H}_{(\mathrm{aq})}{ }^{+}+\mathrm{CO}_{3(\mathrm{aq})}{ }^{2-} \\
2 \mathrm{H}_{(\mathrm{aq})}{ }^{+}+\mathrm{CaSiO}_{3(\mathrm{~s})}=\mathrm{Ca}_{(\mathrm{aq})}{ }^{2+}+\mathrm{H}_{2} \mathrm{O}_{(\mathrm{l})}+\mathrm{SiO}_{2(\mathrm{~s})} \\
\mathrm{Ca}_{(\mathrm{aq})}{ }^{2+}+\mathrm{HCO}_{3(\mathrm{aq})}=\mathrm{CaCO}_{3(\mathrm{~s})}+\mathrm{H}_{(\mathrm{aq})}{ }^{+}
\end{gathered}
$$

According to Wang et al. [27], the activation energy of the process varies between $16 \mathrm{~kJ} / \mathrm{mol}$ and $22 \mathrm{~kJ} / \mathrm{mol}$. There are several methods of carbon mineralization [15], such as

- Ex situ: In which the alkaline source is transported to the capture site of $\mathrm{CO}_{2}$, crushed into small particles, and combined with $\mathrm{CO}_{2}$ at high temperatures and pressure.

- Surficial: Where $\mathrm{CO}_{2}$-bearing and surface waters are reacted with reactive rock fragments, such as alkaline industrial waste (crushed mine tailings). For implementation cost, it is low cost, although a very large area footprint at the gigaton scale is proposed.

- In situ: In which fluids containing $\mathrm{CO}_{2}$ circulate through the porous subsurface in geological formations. These methods have a similar cost to the surficial method of carbon mineralization and a giant storage capacity, but they include uncertain feedback between permeability, reactive surface area, and reaction rate.

- Combined partial enrichment of $\mathrm{CO}_{2}$ using direct air capture with synthetic sorbents plus in situ carbon mineralization or surficial carbon mineralization. In terms of energy requirements and total costs for partial $\mathrm{CO}_{2}$ enrichment, this method involves lower energy than for enrichment to high purity.

In terms of costs, the most economically viable method is in situ carbon mineralization (with a cost capacity of approximately BRL 7-30 per ton of sequestered $\mathrm{CO}_{2}$ ), injecting enriched $\mathrm{CO}_{2}$ into basaltic areas. The total capacities for in situ $\mathrm{CO}_{2}$ sequestration are $8.0 \times 10^{3}-3.5 \times 10^{4} \mathrm{Gt} . \mathrm{CO}_{2}$ for sedimentary formations and $1.0 \times 10^{3}-2.5 \times 10^{5} \mathrm{Gt}^{-\mathrm{CO}_{2}}$ for on-land basalts [15]. The rate and cost of carbon mineralization depend on the amount of $\mathrm{CO}_{2}$ dissolved in solution, alkalinity of the solution, and optimization of reactions, variations in $\mathrm{pH}$ are also important [15].

\section{Wollastonite Synthesis and Some Eco-Friendly Applications}

Wollastonite is a calcium silicate mineral $\left(\mathrm{CaSiO}_{3}\right)$, inert, with a polymorphic structure, being able to be $\alpha$-wollastonite (pseudo wollastonite) at temperatures close to $1125^{\circ} \mathrm{C}$, or $\beta$-wollastonite, which is an important mineral with numerous applications in ceramics, due to its properties: good strength, thermal stability, low dielectric loss, and good bioactivity and biocompatibility $[11,13,25]$. It is a mineral present in tailings of industrial bioproducts (kiln cement ash, steel slag) and which can also be incorporated into the soil, increasing its fertility and high reaction with $\mathrm{CO}_{2}$ (in the range of $8 \times 10^{-9}$ to $2 \times 10^{-7} \mathrm{~mol} \cdot \mathrm{m}^{-2} \cdot \mathrm{s}^{-1}$ at $25^{\circ} \mathrm{C}$ and in the range $1.6 \times 10^{-5}$ to $5 \times 10^{-4} \mathrm{~mol} \cdot \mathrm{m}^{-2} \cdot \mathrm{s}{ }^{-1}$ at $\left.180^{\circ} \mathrm{C}\right)$. However, the availability of wollastonite is low, with global reserves estimated at only $100 \mathrm{M}$ tons $[26,28]$. For carbon mineralization, wollastonite is included in such a non-toxic method [15]. China is the main producer of wollastonite $\left(890 \times 10^{3}\right.$ tons $)$ followed by India $\left(129 \times 10^{3}\right.$ tons $)$ and Mexico $\left(100 \times 10^{3}\right.$ tons $)$ [1].

The reactions below show the potential for $\mathrm{CO}_{2}$ sequestration by wollastonite.

$\mathrm{CO}_{2}$ dissolved in the atmosphere:

$$
2 \mathrm{CO}_{2(\mathrm{~g})}+2 \mathrm{H}_{2} \mathrm{O}_{(\mathrm{l})} \leftrightarrow 2 \mathrm{H}_{2} \mathrm{CO}_{3(\mathrm{aq})} \leftrightarrow 2 \mathrm{HCO}_{3}{ }^{-}+2 \mathrm{H}^{+}
$$

Wollastonite dissolution:

$$
\mathrm{CaSiO}_{3(\mathrm{~s})}+2 \mathrm{H}^{+} \rightarrow \mathrm{Ca}^{2+}+\mathrm{H}_{2} \mathrm{O}_{(\mathrm{l})}+\mathrm{SiO}_{2(\mathrm{~s})}
$$

Precipitation of calcium carbonate:

$$
\mathrm{Ca}^{2+}+2 \mathrm{HCO}_{3}{ }^{-} \rightarrow \mathrm{CaCO}_{3(\mathrm{~s})}+\mathrm{H}_{2} \mathrm{O}_{(\mathrm{l})}+\mathrm{CO}_{2(\mathrm{~g})}
$$


Huang et al. [16] studied cement, which can be partially replaced by wollastonite in cured $\mathrm{CO}_{2}$. The authors applied the LCA ( $1 \mathrm{~m}^{3}$ cement block) for the whole process and found a global warming potential (GWP) of $292 \mathrm{~kg}-\mathrm{CO}_{2} \mathrm{eq}$. For comparison, a Portland cement block has a GWP of $419 \mathrm{~kg}-\mathrm{CO}_{2}$ eq. This result was found with a $20 \%$ replacement of wollastonite. Thinking on a large scale, wollastonite can significantly lower GWP. This study explains how much wollastonite can reduce the environmental $\mathrm{CO}_{2}$ levels if used for replacing cement [1]. In addition, Kusin et al. [3] studied the mineral carbonation of sedimentary mine waste for carbon sequestration, for mineral carbonation, wollastonite can be used as silicate minerals of calcium source. Wollastonite can be reutilized as a raw substance in brickmaking to store $\mathrm{CO}_{2}$ from being released into the atmosphere. For further studies, LCA can be applied to this process in $\mathrm{CO}_{2}$ emission parameters. Wang et al. [29] studied carbon dioxide sequestration via steelmaking slag carbonation, which involves industrial solid wastes. One of the mineral contents in industrial waste is wollastonite. Industrial waste can be found in combustion residues, fly ashes, and slags. The advantage of utilizing industrial solid wastes include being low cost, readily reactive, and having improved quality to the environment after carbonation. Kojima et al. [30] studied the absorption of wollastonite in rocks and found a value of $1.46 \mathrm{mmol} / \mathrm{m}_{2} \mathrm{~h}$ of absorbed $\mathrm{CO}_{2}$, and Sanna et al. [14] studied carbon mineralization technologies in rocks, and for wollastonite found an efficiency of $82 \%$ in $\mathrm{CO}_{2}$ sequestration.

As an alternative, other materials have been used to synthesize wollastonite, one of them is through rice husk/straw ashes. Several studies have been carried out addressing this methodology $[11,13,31]$. The straw / rice husk represents a biodegradable residue, with numerous advantages, such as low acquisition cost, as it is a residue, it can be incorporated into processes, adding value. In quantitative terms, around 570 million tons of rice straw are produced worldwide [31]. Rice is one of the most important foods in the world, responsible for feeding about $75 \%$ of the world's population. In Brazil, it is widely cultivated in a subtropical climate, especially in the southern region of the country, where it has the largest rice-growing area (Table 4) [32]. It is a big opportunity for to Brazil to apply some studies on rice husk residue as a wollastonite source.

Table 4. Total rice production in the 20/21 harvest by region in Brazil (adapted from https: / www. conab.gov.br/info-agro/safras/graos, accessed on 17 November 2021).

\begin{tabular}{|c|c|c|c|}
\hline Region & Area $\left(10^{3} \mathrm{ha}\right)$ & Yield (kg/ha) & Production $\left(10^{3} \mathrm{t}\right)$ \\
\hline North & 233.5 & 4.334 & 1012 \\
\hline Northeast & 168.8 & 2.051 & 342.3 \\
\hline Center-West & 156 & 3.935 & 613.8 \\
\hline Southeast & 10.1 & 4.077 & 41.3 \\
\hline South & 1139.3 & 7.863 & 8958.1 \\
\hline
\end{tabular}

Brazil is one of the largest rice producers outside Asia, currently, the country has about 11 million tons of rice produced, with an area of 1.7 million hectares, and productivity of $6430 \mathrm{~kg} / \mathrm{ha}$ [33]. Figure 4 shows the world data of rice production between the years 1994-2019, where the Asian region holds most of the world's rice production. 


\section{Top countries based on production of rice paddy}

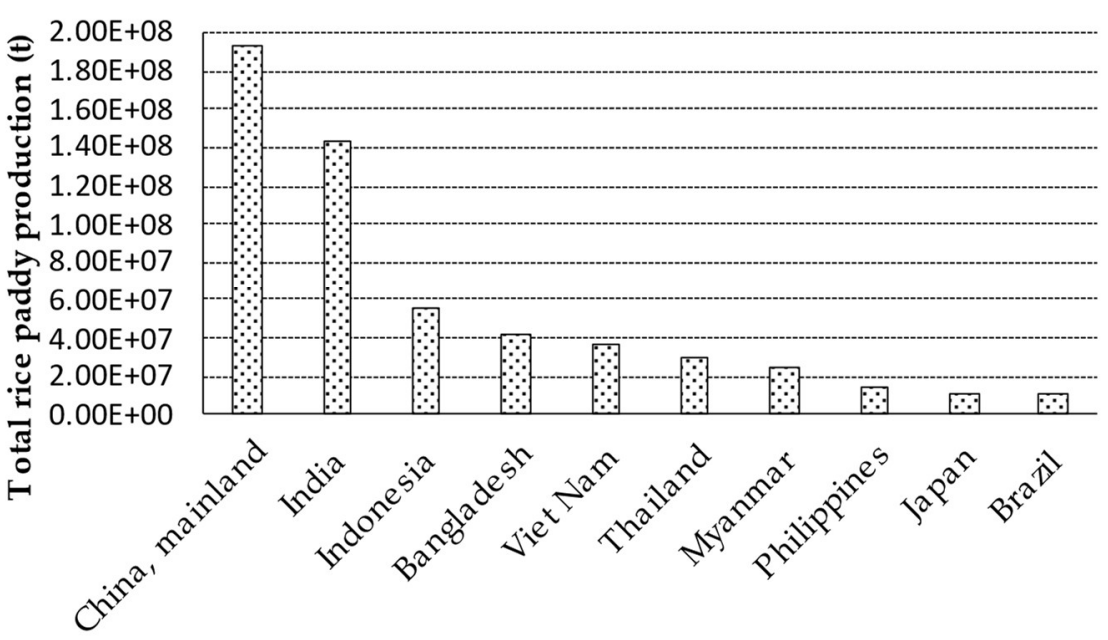

Figure 4. Top rice-producing countries: 1994-2019 (adapted from http:/ / www.fao.org/faostat/en/ \#data/QC/visualize, accessed on 17 November 2021).

According to IRGA data (2021) (https:/ / irga.rs.gov.br/upload/arquivos/202106/101 25554-custos-de-producao-2020--2021.pdf, accessed on 17 November 2021), the weighted average cost to produce a $50 \mathrm{~kg}$ paddy rice in the 2020/2021 harvest in the state of Rio Grande do Sul (RS) was BRL 72.73. The cost per hectare was BRL 11,567.74, considering an average yield of $7952.50 \mathrm{~kg} / \mathrm{ha}-159.05 \mathrm{bags} / \mathrm{ha}$ (average RS).

One of the limitations in rice cultivation is the extreme weather conditions, such as the dry season. Rice production in Brazil is divided into two systems: lowland and upland. About $82 \%$ of all rice production comes from the lowland, while the upland plays an important economic and social role. Rice production in upland areas comprises the savanna region (Mato Grosso, Rondônia, Tocantins, and Goiás); additionally, this region is resistant to drought in a period of water scarcity [33-35]. Rice is stored in metal silos until processed. Several types of rice can be obtained after being husked: wholegrain, polished, and parboiled [32]. A by-product of rice is its straw, which often comprises a residue from rice cultivation. Rice straw is traditionally removed from the crop through open burning. This practice is recurrently adopted to clean and prepare the soil for new plantings [9].

Figure 5 shows an infographic about agricultural residue and how to obtain wollastonite and a specific process. To synthesize materials with wollastonite, several techniques are used, such as the use of an autoclave, involving a hydrothermal process, as shown in the studies by Shamsudin et al. [12], which through the autoclave technique synthesizes $\beta$-wollastonite through rice straw ashes.

Another agricultural residue that can be used as a wollastonite synthesizer is rice husks. During the processing of rice grains, about $80 \mathrm{wt} . \%$ is obtained in the form of rice and the other $20 \mathrm{wt} . \%$ corresponds to rice by-products such as husk [36]. Rice husk contains about $70-80 \%$ volatile organic matter, and a remaining ( $20-30 \%)$ in mineral components such as silica and trace elements, which has low nutritional value and takes a long time to decompose, and is not recommended for animal feed, composting and other processes, such as incorporation into manure. However, rice husks have a significant caloric value ( $\sim 800 \mathrm{~kW} /$ ton), which can be used as fuel in the generation of bioenergy in boilers. Rice husks are mainly composed of silica (92 wt.\%) [28]. Another organic waste is rice husk ash (RHA), which is generated from the burning of rice husks for energy production. In Brazil, the production of RHA is around 0.44 million tons per year, which is mainly applied to agricultural soils [37]. 


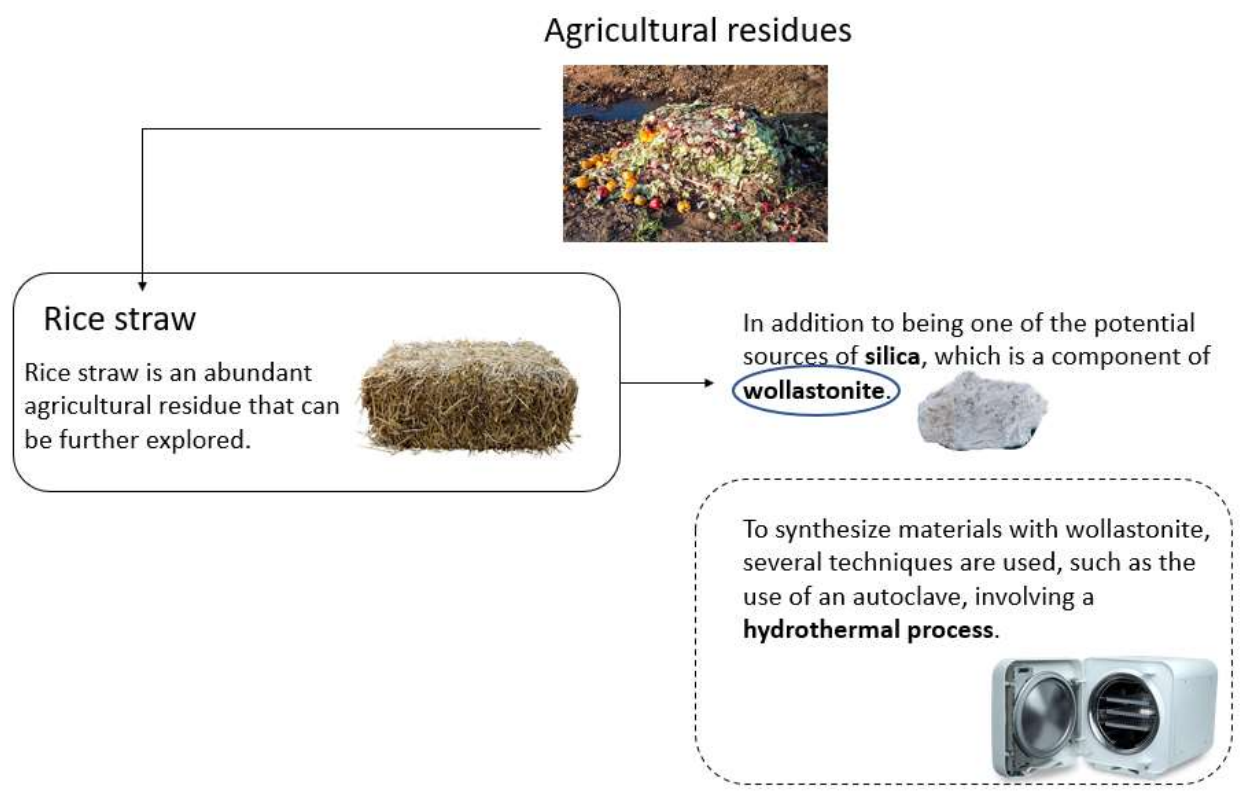

Figure 5. Wollastonite obtained from agricultural residues (adapted from [12]).

Several studies referring to wollastonite synthesis through rice husks are found. Azam et al. [38] synthesized $\alpha$-wollastonite through rice husk ash. Shamsudin et al. [31] synthesized $\beta$-wollastonite from rice husk ash and limestone. In addition, Gotlib et al. [39] studied the impact of production temperature of synthetic wollastonite filled with rice husk. According to studies by Hossain et al. [40], $200 \mathrm{~kg}$ of rice husk, when burned, generates around $50 \mathrm{~kg}(25 \%)$ of rice husk ash, a volume that contains about $45 \mathrm{~kg}(\sim 85-95 \%)$ of amorphous silica, used in the synthesis of wollastonite. In the process of wollastonite synthesis, $\mathrm{CO}_{2}$ is released, for determining the amount, further studies are necessary, such as LCA. Making a parallel to the Brazilian scenario, where around 11 million tons of rice are produced, following this rate, it would be enough to produce 2.475 million tons of amorphous silica. One of the great challenges to be faced when synthesizing wollastonite by bioproducts, such as rice husk, is that the global volume of extraction that for naturally occurring wollastonite cannot cover the industrial demand. For this, it is necessary for an increase in industrial production of synthetic wollastonite by cheap and renewable materials, such as rice husk, evidencing a great opportunity for rice husk waste, promoting a circular economy [39]. There are several advantages for rice processing industries that use raw materials, in particular, bioproducts such as non-dangerous chemicals are used, which reduces the pollution due to open burning or rice husk. In addition, no purification steps are necessary, which helps costs and waste dumping (process as well as release of toxic gases and hazardous chemicals) [39]. On the other hand, there are global impacts of utilizing such agro-industrial wastes such as rice husks.

\section{Global Impacts of Synthesis of Wollastonite by Rice Husk}

Another greenhouse gas (beyond $\mathrm{CO}_{2}$ ) that has a direct impact on global warming is methane $\left(\mathrm{CH}_{4}\right)$, this gas, added to other gases such as ammonia $\left(\mathrm{NH}_{3}\right)$ and other nitrogenous components is mainly generated by animals and agricultural activities. Methane is a powerful greenhouse gas, stronger than $\mathrm{CO}_{2}$ (25 times higher), and its concentration has more than doubled compared to the pre-industrial period (ranging from 700 to $1800 \mathrm{ppb}$ ) [41].

There are numerous sources of methane emissions, as can be observed in Figure 6, mainly: methane from fossil fuels (natural gas), which can be emitted into the atmosphere through oil extraction processes, or by leakage during extraction, and by natural gas storage, and methane emissions by the waste sector, which increases with the digestion of organic 
matter in the waste by microorganisms. However, the main activities responsible for most of the methane emissions are flooded areas and agriculture (339 MT of methane).

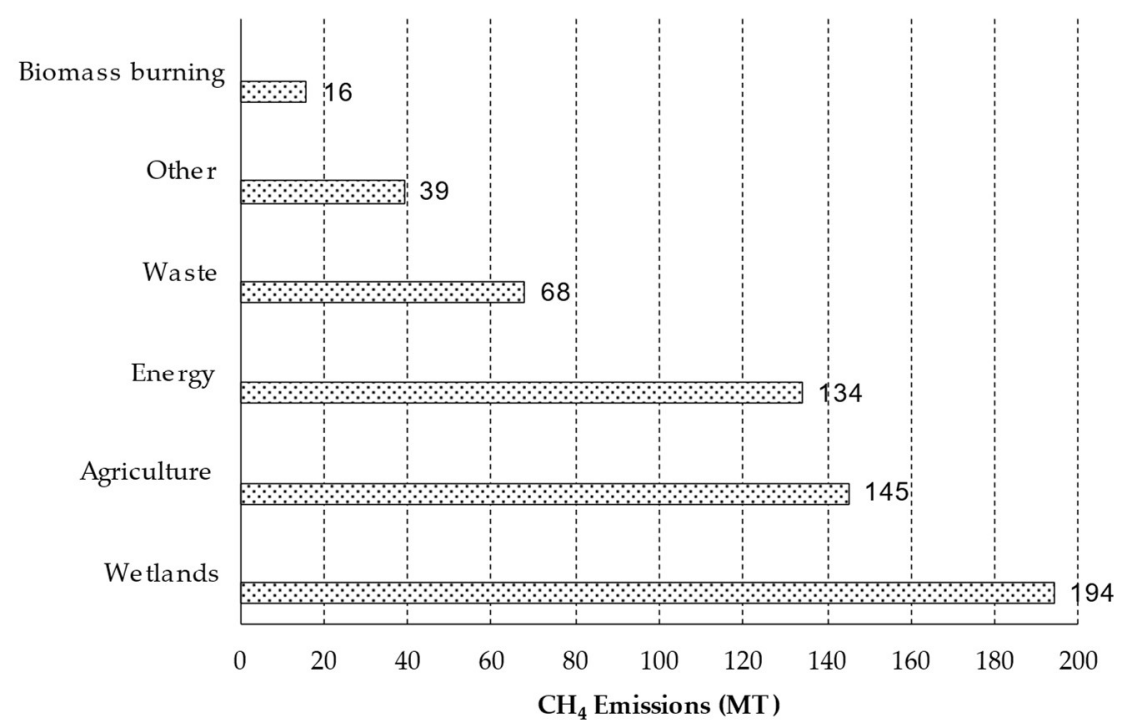

Figure 6. Main global sources of methane emissions (adapted from https: / / www.iea.org/reports / methane-tracker-2020, accessed on 17 November 2021).

Among the sources of agriculture, the main responsible for the largest amount of methane emissions (almost 30\% of the total) is enteric fermentation, which is a digestive process, in which, through biochemical reactions inside the cattle, they produce methane as a by-product. A significant amount of methane emissions is the cultivation of rice (about 11\%), when it is produced in wetlands, under anaerobic conditions, it facilitates the generation of methane (Table 5) [42].

Table 5. Main anthropogenic methane emissions sources within the agriculture sector (adapted [43]).

\begin{tabular}{cc}
\hline Agriculture Sector & Methane Emissions (\%) \\
\hline Enteric fermentation & 66.89 \\
Rice cultivation & 24.26 \\
Manure management & 7.70 \\
Agricultural waste burning & 1 \\
\hline
\end{tabular}

Irrigated rice cultivation by floods constitutes one of the anthropogenic sources of methane, mainly in flooded areas, which are responsible for about $80 \%$ of rice production in the world and in Brazil [42]. Anaerobic decomposition of organic material in flooded rice fields produces methane, which escapes to the atmosphere primarily through rice plantmediated transport (IPCC (2006)) (https://www.ipcc-nggip.iges.or.jp/public/2006gl/, accessed on 17 November 2021).

In Brazil, the Pantanal region is one of the largest wetlands, where the main economic activity is cattle raising. The contribution of Brazilian cattle to the emission of greenhouse gases has been gaining attention in recent decades, mainly due to enteric fermentation and deforestation. In 2010, the Brazilian agricultural sector accounted for $35 \%$ of $\mathrm{CO}_{2}$ emissions-eq by human activities, of which $56.4 \%$ is due to enteric fermentation of methane from livestock [44]. According to data from FAO (2018) (http:/ / www.fao.org/faostat/en/ \#data/GR, accessed on 17 November 2021), the total methane emission from flooded rice cultivation in Brazil in 2018 was estimated at $120.92 \mathrm{Gg} \mathrm{CH}_{4}$, a value $31.62 \%$ lower than in $2010\left(176.85 \mathrm{Gg} \mathrm{CH}_{4}\right)$. This reduction was due to the reduction in the harvested area. Figure 7 presents the methane emission from flooded rice cultivation in Brazil (2010-2018). 


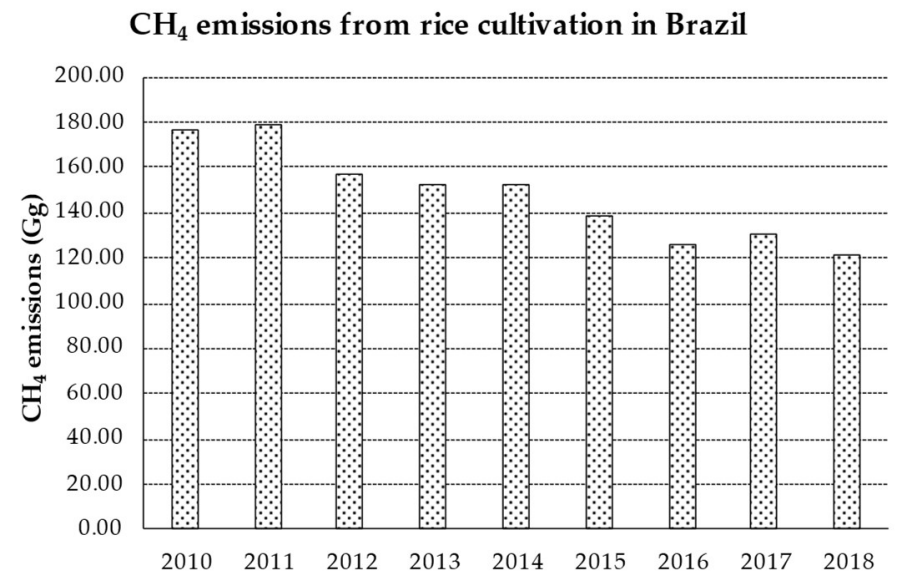

Figure 7. Annual $\mathrm{CH}_{4}$ emissions from flooded rice cultivation in Brazil: 2010-2018 (adapted from http:/ / www.fao.org/faostat/en/\#data/GR, accessed on 17 November 2021).

However, when analyzing the $\mathrm{CH}_{4}$ emission by region in the country considering the period 1990-2005, the most recent data from EMBRAPA (https:/ /livroaberto.ibict.br, accessed on 17 November 2021) shows that the south region has the highest methane emission during the entire period from 2010 to 2018 (Figure 8). This can be linked to the data in Table 4, in which the southern region of the country has the largest area of cultivation, productivity, and production of rice.

Evolution of $\mathrm{CH}_{4}$ emissions from rice cultivation in Brazil regions over the years

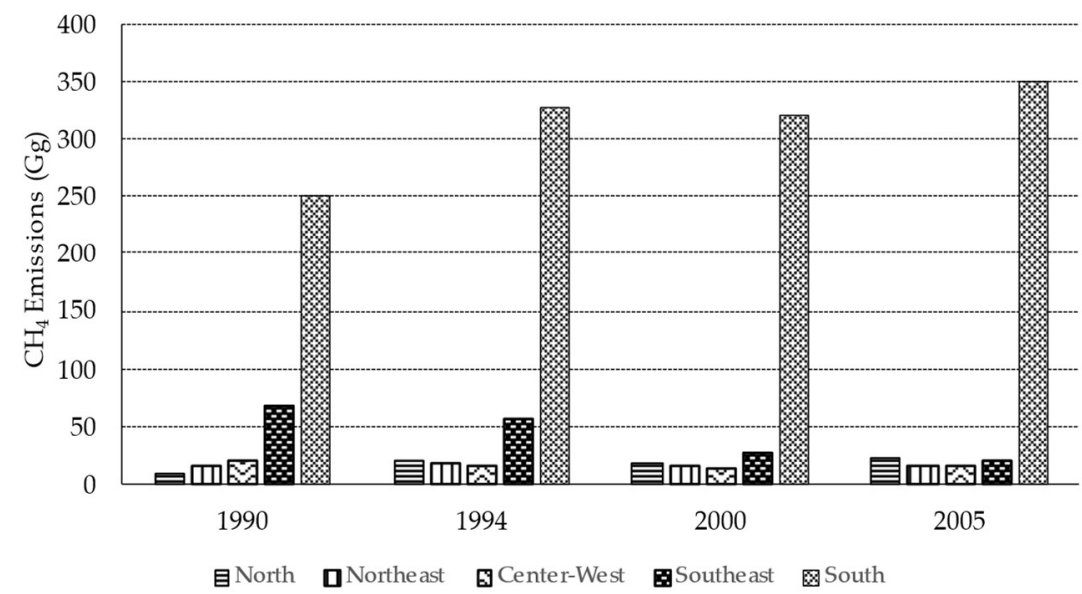

Figure 8. $\mathrm{CH}_{4}$ emissions from flooded rice cultivation in the five Brazilian regions (adapted from https:/ /livroaberto.ibict.br, accessed on 17 November 2021).

Methane is not the only one that causes negative environmental impacts on rice plantations. Jing et al. [45] studied how the increase in the $\mathrm{CO}_{2}$ concentration and temperature rise could modify the physicochemical properties of starch and rice granules, altering their flavors. Since the $\mathrm{CH}_{4}$ issue can be reduced with better assimilation of $\mathrm{CO}_{2}$, it is of paramount importance to curb these impacts. Since the largest emission of methane occurs in flooded areas, studies that enable mitigation are plausible, and one of them is the use of rice husk/straw in the synthesis of wollastonite for storage of $\mathrm{CO}_{2}$.

\section{Energy and Biodiversity}

The conversion of biomass residues from rice production into energy is another great opportunity to promote a circular economy and biodiversity. Agricultural wastes such as 
rice husk and rice straw have a great potential application for power generation. Figure 9 shows some of these applications.

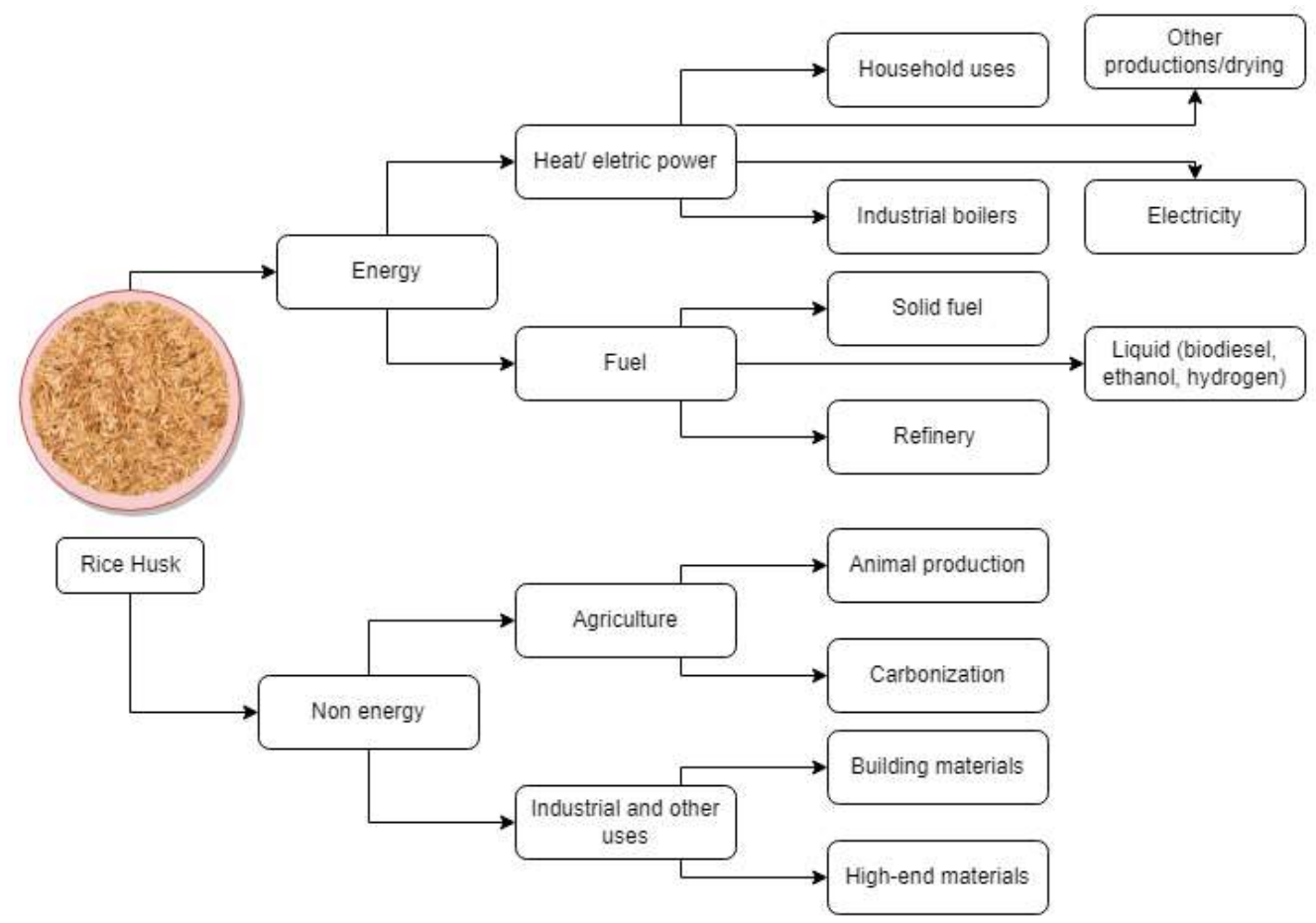

Figure 9. Some applications of rice husk. (adapted from [46].)

From every ton of rice grain obtained, there is, moreover, 1.35 tons of rice straw residue, it becomes clear that the amount of agricultural rice waste straw residue produced is extremely high. Table 6 below, shows the amount of rice crop and predicted rice straw and rice husk in the world and their energy potential [46].

Table 6. Rice crop, rice straw, and rice husk production in the top rice-producing countries in 2017. (adapted from [46]).

\begin{tabular}{ccccc}
\hline Countries & $\begin{array}{c}\text { Countries Rice } \\
\text { Crop }\end{array}$ & $\begin{array}{c}\text { Predicted Rice } \\
\text { Husk }\end{array}$ & $\begin{array}{c}\text { Predicted Rice } \\
\text { Straw }\end{array}$ & $\begin{array}{c}\text { Energy } \\
\text { Potential (PJ) }\end{array}$ \\
\hline China, mainland & 212.68 & 42.54 & 212.68 & 638.03 \\
India & 81.38 & 33.70 & 168.50 & 505.50 \\
Indonesia & 48.98 & 16.28 & 81.38 & 244.15 \\
Bangladesh & 42.76 & 9.80 & 48.98 & 146.94 \\
Vietnam & 33.38 & 8.55 & 42.76 & 128.29 \\
Thailand & 25.62 & 6.68 & 33.38 & 100.15 \\
Myanmar & 19.28 & 5.12 & 25.62 & 76.87 \\
Philippines & 12.47 & 3.86 & 19.28 & 57.83 \\
Brazil & 212.68 & 2.49 & 12.47 & 37.41 \\
\hline
\end{tabular}

As observed in Table 6, Brazil is the only country out of Asia competing in global rice crop production, it is showing its potential as a Latin American country in the use of the biomass of rice for potential energy. The conversion route of rice crop residues into power involves two processes: thermochemical and biochemical processes. The choice of process depends on some factors, such as the amount of biomass feedstock, economic conditions, and project-specific factors. The thermochemical process can be classified into two categories: direct conversion of biomass to energy products and the conversion of biomass into another form that can be to produce energy. In this process, pyrolysis, gasification, and direct combustion are involved. 
On the other hand, the biochemical process of conversations involves some other processes, such as anaerobic digestion and fermentation [46]. Some studies on the conversion of rice crop residues have taken place. Cheewaphongphan et al. [47] studied the potential of rice straws as a supplementary fuel in very small power plants. The global potential of rice straws in this study that was burned was about $3.85 \mathrm{Mt}$, which could be used for heat and electricity production. In addition, Nanzhhu et al. [48] analyzed the pyrolysis and the gasification process of rice straw feedstock. Grotto et al. [49] studied the energy potential of rice husk biomass in Brazil. In their studies, the authors reached the value of 4488,00 $\mathrm{kcal} . \mathrm{kg}^{-1}$ for rice husk, proving the energetic potential of these materials. Therefore, rice husk residue as biomass to produce energy is a very attractive way to end this waste.

\section{Conclusions}

This work presents an overview of the studies of rice husk/straw ash as a precursor in the synthesis of the mineral wollastonite, which can be used as a greenhouse gas sink, such as $\mathrm{CO}_{2}$. Since rice in Brazil is mostly cultivated in wetlands, these areas contribute to a larger scale in the generation of greenhouse gases, especially $\mathrm{CH}_{4}$. First, this work addressed climate environmental problems, such as the greenhouse effect and climate change, highlighting the importance of studies on tools, such as CCS, which aims to capture/store such greenhouse gases (mainly $\mathrm{CO}_{2}$ ). Among the carbon capture and storage methods, mineral carbonation by wollastonite was highlighted, which can be synthesized to reuse agricultural residues, such as rice husk/straw ash. Therefore, according to the studies presented, wollastonite from rice residues presents promising results in the storage of $\mathrm{CO}_{2}$, constituting an important CCS tool and contributing positively to climate change, with a significant impact in Brazil.

Author Contributions: Literature research, C.B.P.; validation, P.R.R., L.J.R.N. and L.C.d.M.; data curation, C.B.P.; writing—original draft preparation, C.B.P.; writing—review, P.R.R., L.J.R.N. and L.C.d.M.; editing, C.B.P. and L.J.R.N.; supervision, L.C.d.M. All authors have read and agreed to the published version of the manuscript.

Funding: This research was funded by Coordenação de Aperfeiçoamento de Pessoal de Nível Superior (88887.608916/2021-00). L.J.R.N. was supported by pro Metheus-Research Unit on Energy, Materials and Environment for Sustainability-UIDP/05975/2020, funded by national funds through FCT—Fundação para a Ciência e Tecnologia.

Institutional Review Board Statement: Not applicable.

Informed Consent Statement: Not applicable.

Data Availability Statement: The data will be made available at reasonable request from the corresponding author.

Acknowledgments: The authors would like to thank Coordenação de Aperfeiçoamento de Pessoal de Nível Superior (CAPES) for financial support (88887.608916/2021-00) and Unesp Sorocaba-ICTS.

Conflicts of Interest: The authors declare no conflict of interest.

\section{References}

1. Nair, N.A.; Sairam, V. Research initiatives on the influence of wollastonite in cement-based construction material-A review. J. Clean. Prod. 2021, 283, 124665. [CrossRef]

2. Gestão, R.D.E.; Sustentabilidade, A.E.; Luisa, A.; Netto, A.; Alves, V.H. Overview of public policies and strategies for the deployment of carbon capture and storage: Reflections for Brazil. J. Environ. Manag. Sustain. 2021, 10, 1-21.

3. Kusin, F.M.; Hasan, S.N.M.S.; Hassim, M.A.; Molahid, V.L.M. Mineral carbonation of sedimentary mine waste for carbon sequestration and potential reutilization as cementitious material. Environ. Sci. Pollut. Res. 2020, 27, 12767-12780. [CrossRef] [PubMed]

4. Alami, A.H.; Alasad, S.; Ali, M.; Alshamsi, M. Investigating algae for $\mathrm{CO}_{2}$ capture and accumulation and simultaneous production of biomass for biodiesel production. Sci. Total Environ. 2021, 759, 143529. [CrossRef]

5. Bhola, V.; Swalaha, F.; Ranjith Kumar, R.; Singh, M.; Bux, F. Overview of the potential of microalgae for $\mathrm{CO}_{2}$ sequestration. Int. J. Environ. Sci. Technol. 2014, 11, 2103-2118. [CrossRef] 
6. Dey, S.; Dhal, G.C. Materials progress in the control of $\mathrm{CO}$ and $\mathrm{CO}_{2}$ emission at ambient conditions: An overview. Mater. Sci. Energy Technol. 2019, 2, 607-623. [CrossRef]

7. Hajilary, N.; Rezakazemi, M.; Shahi, A. $\mathrm{CO}_{2}$ emission reduction by zero flaring startup in gas refinery. Mater. Sci. Energy Technol. 2020, 3, 218-224. [CrossRef]

8. Neeraj, Y.S.; Yadav, S. Carbon storage by mineral carbonation and industrial applications of $\mathrm{CO}_{2}$. Mater. Sci. Energy Technol. 2020, 3, 494-500. [CrossRef]

9. Friedlingstein, P.; O'Sullivan, M.; Jones, M.W.; Andrew, R.M.; Hauck, J.; Olsen, A.; Peters, G.P.; Peters, W.; Pongratz, J.; Sitch, S.; et al. Global Carbon Budget 2020. Earth Syst. Sci. Data 2020, 12, 3269-3340. [CrossRef]

10. Mokhtara, C.; Negrou, B.; Bouferrouk, A.; Yao, Y.; Settou, N.; Ramadan, M. Integrated supply-demand energy management for optimal design of off-grid hybrid renewable energy systems for residential electrification in arid climates. Energy Convers. Manag. 2020, 221, 113192. [CrossRef]

11. Ismail, H.; Shamsudin, R.; Abdul Hamid, M.A.; Jalar, A. Synthesis and characterization of nano-wollastonite from rice husk ash and limestone. Mater. Sci. Forum 2013, 756, 43-47. [CrossRef]

12. Shamsudin, R.; Ismail, H.; Hamid, M.A.A. The suitability of rice straw ash as a precursor for synthesizing $\beta$-wollastonite. Mater. Sci. Forum 2016, 846, 216-222. [CrossRef]

13. Ismail, H.; Shamsudin, R.; Hamid, M.A.A.; Awang, R. Characteristics of $\beta$-wollastonite derived from rice straw ash and limestone. J. Aust. Ceram. Soc. 2016, 52, 163-174.

14. Sanna, A.; Uibu, M.; Caramanna, G.; Kuusik, R.; Maroto-Valer, M.M. A review of mineral carbonation technologies to sequester $\mathrm{CO}_{2}$. Chem. Soc. Rev. 2014, 43, 8049-8080. [CrossRef]

15. Kelemen, P.; Benson, S.M.; Pilorgé, H.; Psarras, P.; Wilcox, J. An Overview of the Status and Challenges of $\mathrm{CO}_{2}$ Storage in Minerals and Geological Formations. Front. Clim. 2019, 1, 9. [CrossRef]

16. Huang, H.; Guo, R.; Wang, T.; Hu, X.; Garcia, S.; Fang, M.; Luo, Z.; Maroto-Valer, M.M. Carbonation curing for wollastonitePortland cementitious materials: $\mathrm{CO}_{2}$ sequestration potential and feasibility assessment. J. Clean. Prod. 2019, $211,830-841$. [CrossRef]

17. Pastero, L.; Curetti, N.; Ortenzi, M.A.; Schiavoni, M.; Destefanis, E.; Pavese, A. $\mathrm{CO}_{2}$ capture and sequestration in stable Ca-oxalate, via Ca-ascorbate promoted green reaction. Sci. Total Environ. 2019, 666, 1232-1244. [CrossRef]

18. Bao, J.; Lu, W.-H.; Zhao, J.; Bi, X.T. Greenhouses for $\mathrm{CO}_{2}$ sequestration from atmosphere. Carbon Resour. Convers. 2018, 1, 183-190. [CrossRef]

19. SundarRajan, P.S.; Gopinath, K.P.; Greetham, D.; Antonysamy, A.J. A review on cleaner production of biofuel feedstock from integrated $\mathrm{CO}_{2}$ sequestration and wastewater treatment system. J. Clean. Prod. 2019, 210, 445-458. [CrossRef]

20. Rosa, L.; Sanchez, D.L.; Realmonte, G.; Baldocchi, D.; D'Odorico, P. The water footprint of carbon capture and storage technologies. Renew. Sustain. Energy Rev. 2021, 138, 110511. [CrossRef]

21. Wang, J.W.; Kang, J.N.; Liu, L.C.; Nistor, I.; Wei, Y.M. Research trends in carbon capture and storage: A comparison of China with Canada. Int. J. Greenh. Gas Control 2020, 97, 103018. [CrossRef]

22. Vieira, L.C.; Amaral, F.G. Barriers and strategies applying Cleaner Production: A systematic review. J. Clean. Prod. 2016, 113, 5-16. [CrossRef]

23. Soong, Y.; Howard, B.H.; Hedges, S.W.; Haljasmaa, I.; Warzinski, R.P.; Irdi, G.; McLendon, T.R. $\mathrm{CO}_{2}$ sequestration in saline formation. Aerosol Air Qual. Res. 2014, 14, 522-532. [CrossRef]

24. Min, Y.; Jun, Y.S. Wollastonite carbonation in water-bearing supercritical $\mathrm{CO}_{2}$ : Effects of water saturation conditions, temperature, and pressure. Chem. Geol. 2018, 483, 239-246. [CrossRef]

25. Haque, F.; Santos, R.M.; Chiang, Y.W. $\mathrm{CO}_{2}$ sequestration by wollastonite-amended agricultural soils-An Ontario field study. Int. J. Greenh. Gas Control 2020, 97, 103017. [CrossRef]

26. Kelemen, P.B.; McQueen, N.; Wilcox, J.; Renforth, P.; Dipple, G.; Vankeuren, A.P. Engineered carbon mineralization in ultramafic rocks for $\mathrm{CO}_{2}$ removal from air: Review and new insights. Chem. Geol. 2020, 550, 119628. [CrossRef]

27. Wang, F.; Dreisinger, D.; Jarvis, M.; Hitchins, T. Kinetics and mechanism of mineral carbonation of olivine for $\mathrm{CO}_{2}$ sequestration. Miner. Eng. 2019, 131, 185-197. [CrossRef]

28. Hossain, S.S.; Roy, P.K. Study of physical and dielectric properties of bio-waste-derived synthetic wollastonite. J. Asian Ceram. Soc. 2018, 6, 289-298. [CrossRef]

29. Wang, C.Y.; Bao, W.J.; Guo, Z.C.; Li, H.Q. Carbon Dioxide Sequestration via Steelmaking Slag Carbonation in Alkali Solutions: Experimental Investigation and Process Evaluation. Acta Metall. Sin. 2018, 31, 771-784. [CrossRef]

30. Kojima, T.; Nagamine, A.; Ueno, N.; Uemiya, S. Absorption and fixation of carbon dioxide by rock weathering. Energy Convers. Manag. 1997, 38, 461-466. [CrossRef]

31. Shamsudin, R.; Abdul Azam, F.A.; Abdul Hamid, M.A.; Ismail, H. Bioactivity and cell compatibility of $\beta$-wollastonite derived from rice husk ash and limestone. Materials 2017, 10, 1188. [CrossRef] [PubMed]

32. Savi, G.D.; Piacentini, K.C.; Rocha, L.O.; Carnielli-Queiroz, L.; Furtado, B.G.; Scussel, R.; Zanoni, E.T.; Machado-de-Ávila, R.A.; Corrêa, B.; Angioletto, E. Incidence of toxigenic fungi and zearalenone in rice grains from Brazil. Int. J. Food Microbiol. 2018, 270, 5-13. [CrossRef] [PubMed] 
33. Avila, C.F.; Moreira, G.M.; Nicolli, C.P.; Gomes, L.B.; Abreu, L.M.; Pfenning, L.H.; Haidukowski, M.; Moretti, A.; Logrieco, A.; del Ponte, E.M. Fusarium incarnatum-equiseti species complex associated with Brazilian rice: Phylogeny, morphology and toxigenic potential. Int. J. Food Microbiol. 2019, 306, 108267. [CrossRef]

34. Heinemann, A.B.; Ramirez-Villegas, J.; Rebolledo, M.C.; Costa Neto, G.M.F.; Castro, A.P. Upland rice breeding led to increased drought sensitivity in Brazil. F. Crop. Res. 2019, 231, 57-67. [CrossRef]

35. Fageria, N.K.; Wander, A.E.; Silva, S.C. Rice (Oryza sativa) cultivation in Brazil. Indian J. Agron. 2014, 59, $350-358$.

36. Hossain, S.S.; Yadav, S.; Majumdar, S.; Krishnamurthy, S.; Pyare, R.; Roy, P.K. A comparative study of physico-mechanical, bioactivity and hemolysis properties of pseudo-wollastonite and wollastonite glass-ceramic synthesized from solid wastes. Ceram. Int. 2020, 46, 833-843. [CrossRef]

37. da Silva, M.T.; Martinazzo, R.; Silva, S.D.A.; Bamberg, A.L.; Stumpf, L.; Fermino, M.H.; Kohler, T.W.; Matoso, E.S.; Valgas, R.A. Innovative substrates for sugarcane seedling production: Sewage sludges and rice husk ash in a waste-to-product strategy. Ind. Crops Prod. 2020, 157, 112812. [CrossRef]

38. Azam, F.A.A.; Shamsudin, R.; Ng, M.H.; Ahmad, A.; Akbar, M.A.M.; Rashidbenam, Z. Silver-doped pseudowollastonite synthesized from rice husk ash: Antimicrobial evaluation, bioactivity and cytotoxic effects on human mesenchymal stem cells. Ceram. Int. 2018, 44, 11381-11389. [CrossRef]

39. Gotlib, E.; Tverdov, I.; Phuong, H.T.N.; Sokolova, A. The impact of production temperature of synthetic wollastonite filled with rice husk on its composition and modifying effect. IOP Conf. Ser. Mater. Sci. Eng. 2021, 1030, 012004. [CrossRef]

40. Hossain, S.S.; Mathur, L.; Roy, P.K. Rice husk ash as an alternative source of silica in ceramics: A review Rice husk/rice husk ash as an alternative source of silica in ceramics: A review. J. Asian Ceram. Soc. 2018, 6, 299-313. [CrossRef]

41. de Miranda, M.S.; Fonseca, M.L.; Lima, A.; de Moraes, T.F.; Aparecido Rodrigues, F. Environmental Impacts of Rice Cultivation. Am. J. Plant Sci. 2015, 6, 2009-2018. [CrossRef]

42. Kögel-Knabner, I.; Amelung, W.; Cao, Z.; Fiedler, S.; Frenzel, P.; Jahn, R.; Kalbitz, K.; Kölbl, A.; Schloter, M. Biogeochemistry of paddy soils. Geoderma 2010, 157, 1-14. [CrossRef]

43. Janssens-Maenhout, G.; Crippa, M.; Guizzardi, D.; Muntean, M.; Schaaf, E.; Dentener, F.; Bergamaschi, P.; Pagliari, V.; Olivier, J.; Peters, J.; et al. EDGAR v4.3.2 Global Atlas of the three major Greenhouse Gas Emissions for the period 1970-2012. Earth Syst. Sci. Data Discuss. 2017, 3, 1-55. [CrossRef]

44. Bergier, I.; Silva, A.P.S.; de Abreu, U.G.P.; de Oliveira, L.O.F.; Tomazi, M.; Dias, F.R.T.; Urbanetz, C.; Nogueira, É.; Borges-Silva, J.C. Could bovine livestock intensification in Pantanal be neutral regarding enteric methane emissions? Sci. Total Environ. 2019, 655, 463-472. [CrossRef]

45. Jing, L.; Chen, C.; Lu, Q.; Wang, Y.; Zhu, J.; Lai, S.; Wang, Y.; Yang, L. How do elevated atmosphere $\mathrm{CO}_{2}$ and temperature alter the physiochemical properties of starch granules and rice taste? Sci. Total Environ. 2021, 766, 142592. [CrossRef]

46. Mofijur, M.; Mahlia, T.M.I.; Logeswaran, J.; Anwar, M.; Silitonga, A.S.; Rahman, S.M.A.; Shamsuddin, A.H. Potential of rice industry biomass as a renewable energy source. Energies 2019, 12, 4116. [CrossRef]

47. Cheewaphongphan, P.; Junpen, A.; Kamnoet, O.; Garivait, S. Study on the potential of rice straws as a supplementary fuel in very small power plants in Thailand. Energies 2018, 11, 270. [CrossRef]

48. Ai, N.; Chen, L.; Fu, Y. A novel analysis on pyrolysis and gasification process of rice straw feedstock. Sustain. Energy Technol. Assess. 2022, 51, 101866. [CrossRef]

49. Lopes Grotto, C.G.; Gomes Colares, C.J.; Lima, D.R.; Pereira, D.H.; Teixeira do Vale, A. Energy potential of biomass from two types of genetically improved rice husks in Brazil: A theoretical-experimental study. Biomass Bioenergy 2020, 142, 105816. [CrossRef] 